\title{
DISCOURSE ON SERVICE MODULARITY: INVESTIGATING SERVICE DELIVERY PROCESS
}

\author{
Ilona SKAČKAUSKIENE்(D), Jurga VESTERTE் (D* \\ Department of Management, Faculty of Business Management, Vilnius Gediminas Technical University, \\ Saulètekio al. 11, 10223, Vilnius, Lithuania \\ *E-mail: jurga.vesterte@vgtu.lt
}

\begin{abstract}
Purpose - the purpose of this research is to determine aspects of the service delivery process what must be considered for modularisation. The aim is reached through (1) investigating the process construct; (2) describing and schematizing service delivery process through integration of customer and provider perspectives; (3) ascertaining the aspects of the service delivery process modularisation.
\end{abstract}

Research methodology - the article is built on an overview of the scientific literature dealing with the topic, using methods of comparative analysis, systemic analysis, abstraction, synthesis, abductive reasoning.

Findings - for achieving service modularisation, the service provider may apply standardisation and automation methods on three dimensions of service delivery process: (1) service offering; (2) parts of the service process that are managed by the provider; (3) organisational structure of the provider.

Research limitations - the study examines the aspects of modularity only on the conceptual level. A natural extension of this research is an empirical investigation of the introduced approaches.

Practical implications - the proposed approaches help practitioners in the decision-making process for a service delivery process modularisation.

Originality/Value - the study approaches the modularisation of the service delivery process considering the customer and service provider perspectives and fills the gap in the literature on service modularisation management.

Keywords: services; service modularity; service delivery process; service management.

JEL Classification: M11.

Conference topic: Contemporary Organizations Development Management.

\section{Introduction}

In today's world, services are not only dominating the economy but are becoming increasingly complex. Perhaps an ordinary customer who uses a transport service or buys a performance ticket via the Internet does not see the complexity of services, but the service provider is well aware of this. Service company needs to be knowledgeable of the advanced technology, participate in business networks and continuously search for a competitive advantage. Satisfying the demands of modern customers is not easy. It is required to offer not only the services tailored to their needs, but also at a competitive price and in the shortest possible time. Service companies face the challenge of delivering customercentred services smoothly and managing their complexity.

One of the possible solutions to overcoming the challenges is to manage the service delivery by applying modular design principles, thus exploiting the benefits of modularity - flexibility, complexity management, the variety of options, and similar. The idea of a modular system can be related to the natural sciences (Levin, 2015) and the development of its application to artificial systems - with systems engineering and information technologies. In the context of management, the modularity has long been associated with the production of goods (Brax, Bask, Hsuan, \& Voss, 2017). However, with services becoming dominant in the global economy (Skačkauskiene \& Vesterte, 2018) and with increasing interest in them, two essential differences between services and goods have been clarified in the operation management and marketing theories (Brax et al., 2017). Firstly, services are of processual nature, and secondly, customer involvement as a resource is necessary for service delivery. These factors forced the review of the application of modular design principles to services. 
The essence of modular design is to create modular type connections in the system while retaining the hierarchical principle and maintaining the functional purpose of the system. When implementing this type of relations, the system is divided into relatively independent, functional-purpose blocks or modules that isolate "invisible" complexity (Baldwin \& Clark, 2000). Module connections to other modules are weak, but connections between elements inside the module are strong. Modules connect through simple, standardised interfaces. Such design reduces the overall complexity of the system, improves flexibility, reliability and maintainability of it.

Most modern services can be considered modular. For example, payment for a service may be made not only in cash but also by various electronic means - a bank card, using an application on a mobile phone, making a bank transfer on the Internet banking website. In other words, a service provider outsources the service sub-process to another service provider. The example demonstrates that it is possible to isolate complexity (cash settlement via electronic channels is very complicated) into the module and its function integrate into the service delivery process through the standard interface. Thus, a provider develops service modularity without having such a purpose in advance. However, it is also possible to apply the modular design principles in the service system intentionally for gaining competitive advantage in the market; and this can be done at different levels of the service system, as noted by the authors of various works (Bask, Lipponen, Rajahonka, \& Tinnilä, 2011; Løkkegaard, Mortensen, \& McAloone, 2016; Pekkarinen \& Ulkuniemi, 2008; Tuunanen, Bask, \& Merisalo-Rantanen, 2012; Voss \& Hsuan, 2009).

Nevertheless the scientists' interest in the modularity of service delivery, this area has not been sufficiently researched compared to modularity in the production of goods (de Mattos, Fettermann, \& Cauchick-Miguel, 2019). The constructs of service modularity lack conceptual refinement and the empirical cases of service modularisation are only exploratory. How a modular design should be applied to deliver a service, what it means to structure a service company in a modular fashion, what management decisions related to modularisation should be made, what conditions should be taken into account - there is not much knowledge in management theory right now. It is worth mentioning that the positive effects of modularity are known though little attention is paid to the negative aspects of it (e.g. excessive decoupling into modules makes it difficult to manage the system). If a service company decides to leverage modularity in the service delivery process, it would need a decision support model that explains the effects of modularity in services and assists in decision rationalisation.

The purpose of the study is to determine aspects of the service delivery process what must be considered in modularisation. The aim is reached through 1) investigating the process construct; 2) describing and schematizing service delivery process through integration of customer and provider perspectives; 3) ascertaining the aspects of the service delivery process modularisation. The paper employs comparative analysis, systemic analysis, abstraction, synthesis, abductive reasoning for achieving the research results.

\section{Service delivery process}

The service is a process that is fundamentally different from the production process of goods (Butkus, 2002; Lillrank, 2010) because it requires customer engagement, and the value accumulates not only at the service delivery stage but also before the customer makes the decision to buy or not to buy a service (Ercsey, 2017). Therefore, in order to describe the service process comprehensively, it is necessary to examine not only the technological side of service delivery but also the aspect of customer participation in it.

Generally, a process represents the sequence of successive activities or the chain of related events. Processes are restrained by space and time; that is to say, it has the beginning and the end; also, the activities involved produce a particular outcome. Management theory views a process as something manageable: it can be planned, specific organisational methods can be applied, it can be controlled for effective performance and outcome quality. Processes can be investigated by selecting the units of analysis (Lillrank, 2010; Merrifield, Calhoun, \& Stevens, 2008) hierarchically: 1) step; 2) group of activities (process); 3) cross-functional processes; 4) supply chain. Depending on a unit of analysis, different management goals are in focus. A brief description of units of analysis is presented in Figure 1.

Regardless of the chosen unit of analysis, process owns characteristical elements. They are 1) logical connectionunits of analysis are connected by cause-effect laws; 2) sequence - the logical relationship between the units of analysis can be realized by fixed (first A, then B), variable (first A, then B or C) or parallel (first A, then B and C together, then D) sequences; 3) handover - the produced result must be transferred from one step to the next; 4) the handover is initiated by the signal indicating that the result is ready for further processing; usually control information accompanies the result.

Three main phases of service delivery process are distinguished in the scientific literature: the beginning, the delivery, the end. The authors call these phases differently (see Table 1), depending on the angle at which services are analysed - customer or service provider perspective, systemic view, etc. However, the content (typical events, episodes and activities) of these phases is similarly arranged regardless of the nature of services.

When investigating the service delivery process, it is important to highlight how the service becomes the final product in the third closing phase. The service consists of many interconnected components, most of which, unlike the goods, are intangible - processes, human knowledge and skills, information flows (Goldstein, Johnston, Duffy, \& Rao, 2002). Managing intangible components is difficult, so it is unclear in advance how they will connect seamlessly before 
any service delivery. Despite this uncertainty, each service organisation has a defined service concept that is expected to be implemented during service delivery. The scientific literature describes the service concept in various ways. Heskett (Heskett, 1986) argues that the service concept defines a particular service image created by the organisation for customers, employees, shareholders, and creditors. The organisation supports this image by the solutions developed in operations, financial, marketing, human resource and quality management. Edvardsson and Olsson (Edvardsson \& Olsson, 1996) suggest comparing the service concept to a service prototype that explains the way a value or benefit will be provided to a customer. According to scientists, the concept of service is a detailed description of what needs to be done to meet customer needs. Clark, with co-authors (Clark, Johnston, \& Shulver, 2000), state that the service

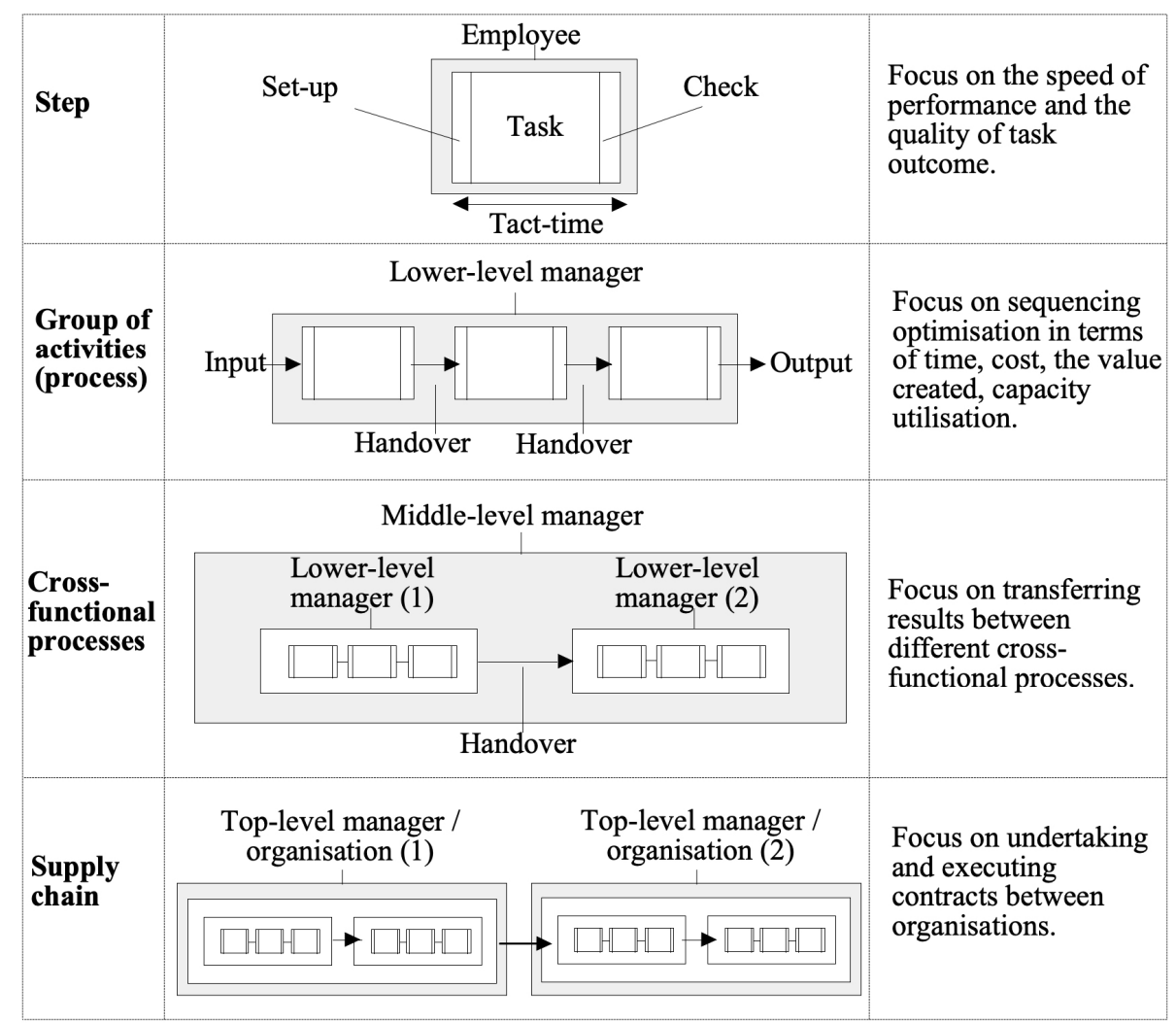

Figure 1. Units of analysis in processes (source: created by authors modifying (Lillrank, 2010))

Table 1 . Service delivery process phases and their content (source: created by authors)

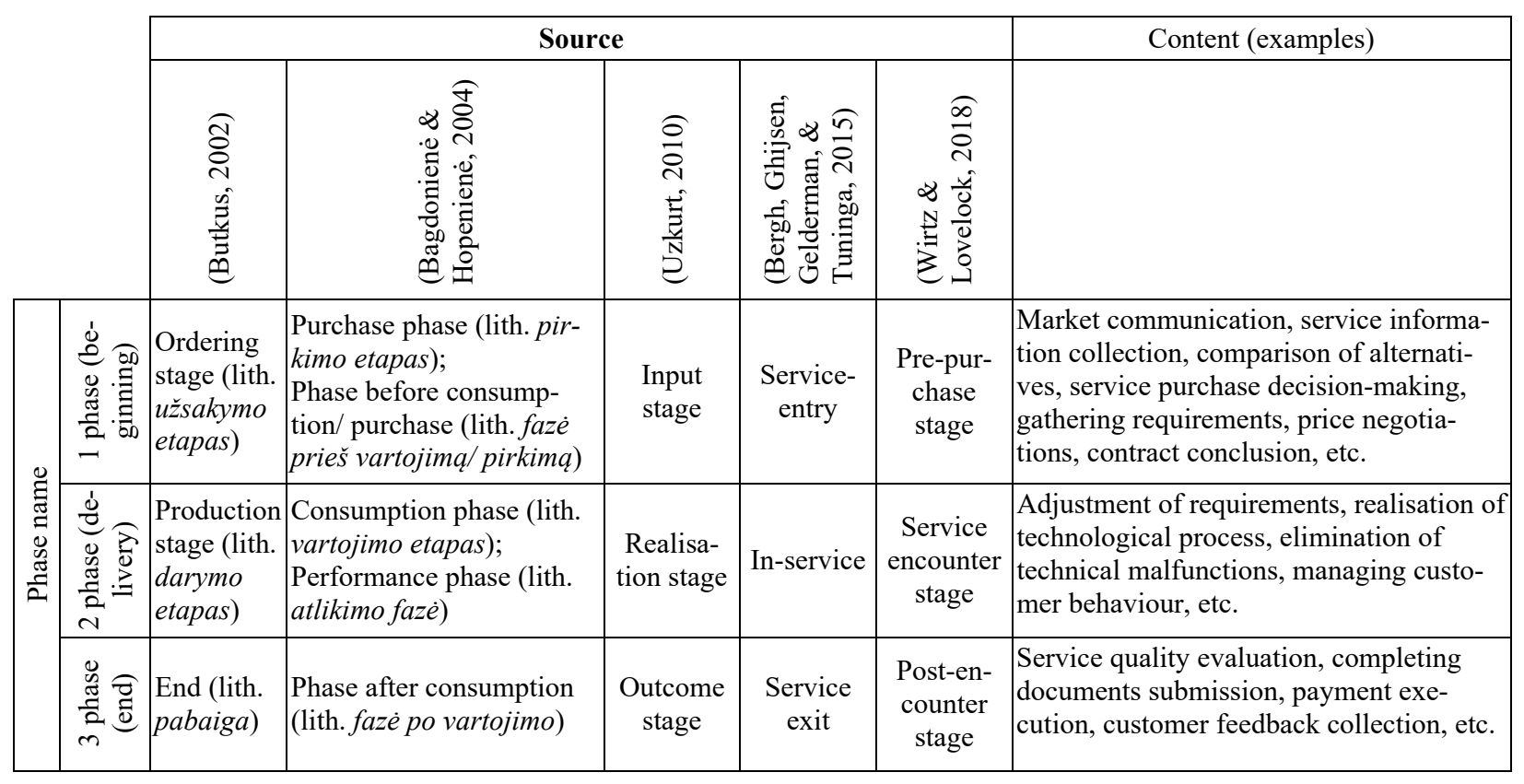


concept includes (1) the value for which customers tend to pay; (2) form and function - how organisation provides a service and what customer needs it satisfies; (3) experience - what experiences the customer will get when receiving the service; (4) results - what benefit, clear or predictable, the customer and the organization will receive. Johnston, with co-authors (Johnston, Clark, \& Shulver, 2012), specify this description and say that the service concept includes information about (1) essence of service purchased and used by customer; (2) service delivery - processes and their results, resources, including those provided by customer participation; (3) service outcome, which is characterized by two aspects: customer experience and benefits. As can be seen from the proposed service concept descriptions, this construct expresses the potential value of the service to be provided and the organisation's readiness to deliver it. The service concept is reformulated into service offering to be the most suitable for customer communication. According to Goldstein and co-authors (Goldstein et al., 2002), the service offering is a promise to the customer that the organisation will perform the required processes, but it cannot confirm their quality at the moment of purchase. Similarly, Grönroos (Grönroos, 2016) describes the service offering as a parallel with goods and claims that it represents a product that is not pre-fabricated and ready for consumption. Service marketing provides a variety service offering models: Molecular Model (Shostack, 1977), Augmented Service Offering Model (Grönroos, 2016; Storey \& Easingwood, 1998), Flower of Service Framework (Wirtz \& Lovelock, 2018). After examining them, it becomes clear that the service offering is the equivalent of a product in the marketing mix. Formulation of a service offering helps the organisation to answer customer questions about price, delivery terms, and volume of work foresee.

The service concept (as formulated by the organisation internally) or the service offering (as presented by the organisation to the customer) becomes the received value during the service process. The service delivery process should be attributed to and analysed as cross-functional processes and supply chain (for specific services) (see Figure 1). As Johnston and his co-authors point out (Johnston et al., 2012), the process of providing a service is a set of interrelated activities that, in the required sequence, materialise the service concept and create the customer experience. Since the customer and service partners are involved in the process, the service can take place not only at the premises of the service provider but also at the customer's and partner's premises, the service organisation cannot control all its parts, but is responsible for the whole process. Because of the customer's involvement, the service delivery process must necessarily be viewed from both - customer's and provider's - perspectives, as only in this way can a complete picture of the delivery process be seen. Analysis of the services delivery from these two perspectives shows that certain service activities are invisible to the customer and the provider, as well as the activities that are visible to both of them, as the involvement of both parties is required. Service marketing and operations management (Johnston et al., 2012; Wirtz \& Lovelock, 2018) attribute non-visible to customer activities to an organisation's operational activities, which mainly include technological service processes and supportive information processes. The customer service activity is performed in the area visible to a customer and a provider. However, in order to use the service, the customer performs actions that are not always visible to the provider. The sequence of actions performed by a customer using own resources for obtaining service is called episodes (Lillrank, 2010). When the episode coincides with the activity of the service delivery process, there is an interaction called service encounter, touchpoint or service event (Lillrank, 2010).

One of the essential elements of the service concept is the customer experience, which is a complex, abstract phenomenon. The way it is formed during service delivery is not sufficiently explored (Lipkin, 2016). The customer experience can be analysed in several aspects: as the accumulation of knowledge (process), caused by a coherent activity or non-linear phenomenological event, and as a result of all service experience (Lipkin, 2016). There is also no consensus on the unified description of this construct (Jain, Aagja, \& Bagdare, 2017). One of the newer, based on the results of a thorough analysis of scientific literature, is introduced by Jain and co-authors (Jain et al., 2017), claiming that the customer experience is the whole of feelings, perceptions and attitudes generated throughout the service consumption chain. It includes interactions with people, objects, processes, and environment that cause cognitive, emotional, sensory, and behavioural responses (reactions). Thus, one of the primary conditions for customer experience is the interactions that take place during the service delivery. The customer experience is accumulated through all three stages of the service delivery process. Customer expectations regarding service offering are formed at the initial stage, and the experience of brand communication is encountered. At the delivery stage, customers mainly collect the transactive and relationship experience that goes hand in hand with routine service activities. At the completion stage, the acquired result is satisfaction (or dissatisfaction) with the service (Jain et al., 2017; O'Loughlin, Szmigin, \& Turnbull, 2004; Wirtz \& Lovelock, 2018).

Identified and investigated aspects of the service delivery process are presented in the scheme (see Figure 2). 


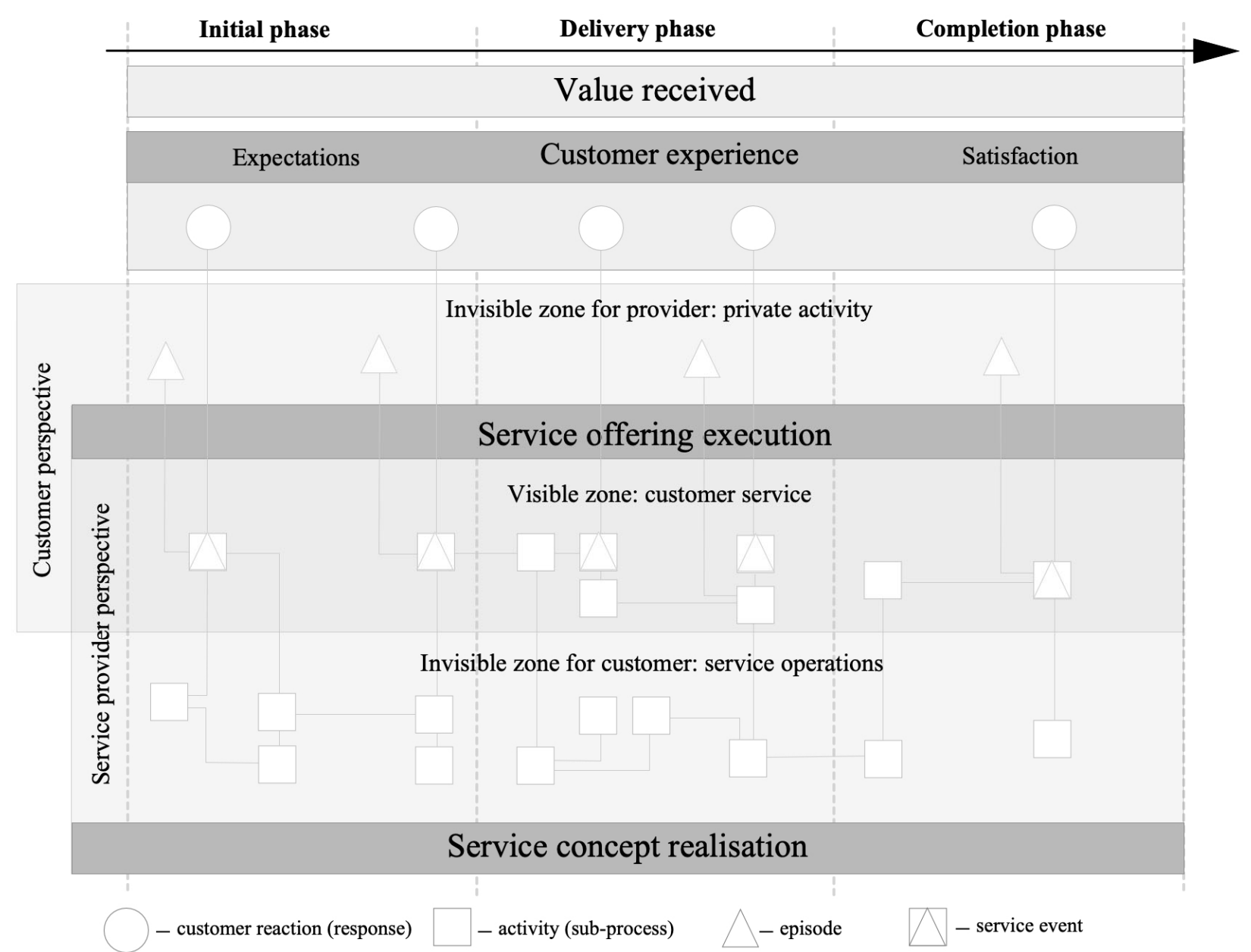

Figure 2. Service delivery process by integrating customer and provider perspectives (source: created by authors)

The diagram shows that the provider while being a subject in the service delivery process, does not entirely manage this process. The actions taken by the customer to use the service may take place in the invisible zone and the area visible to both parties. Depending on how the customer successfully handles the tasks required to obtain the service, the service delivery runs smoothly or not.

\section{Modularity in service delivery}

Two reasons cause the interest to service modularity. Increasing competition in the services sector forces organisations to reduce prices and at the same time, picky customers want better service quality. The way to achieve cost savings is to standardise and automate them. For quality improvement, organisations might consider customisation. These are fundamentally contradictory objectives that determine whether a service organisation chooses the standardisation or customisation direction. Sundbo (Sundbo, 1994) suggests that there is also an intermediate option - to choose a modularity direction (strategy) for designing the service concept and implementing the delivery process. Modularity allows a certain degree of system flexibility and variety of options, without increasing costs, in other words, offers a solution to the challenges mentioned. Application of modular design to services is closely related to standardisation of service offering elements and service sub-processes (Carlborg \& Kindström, 2014) while maintaining a flexible connection between them and thus economically achieving service customisation. Geum and co-authors (Geum, Kwak, \& Park, 2012) affirm that the nature of the service determines whether it is possible to choose the modularity strategy or not applying modular design for mass services is more accessible than for knowledge-intensive (professional) services. However, adoption of advanced information and communication technologies in services shows that service offering elements and sub-processes of knowledge-intensive services can also be successfully standardised (Broekhuis, van Offenbeek, \& Eissens-van der Laan, 2017; Nätti, Ulkuniemi, \& Pekkarinen, 2017).

The idea of modular design is to divide the object (item or process) into parts (modules) in such a way that they can be flexibly connected or separated, if necessary. The investigated service delivery process has shown that a service is a product and a production process at the same time. Therefore, it suggests that this duality of service should be treated as two separate objects (product and process) for the application of modular design. This approach is also 
supported in the scientific literature (Eissens-van der Laan, Broekhuis, van Offenbeek, \& Ahaus, 2016; Pekkarinen \& Ulkuniemi, 2008), saying that the following dimensions should be distinguished: (1) product dimension (what delivered) - the whole of service offering elements that the customer buys; (2) process dimension (how delivered) - customer-provider interactions and activities required for service delivery. Additionally (Eissens-van der Laan et al., 2016), this distinction presupposes a choice for modularising from three possible options: (1) focusing on the service offer; (2) focusing on the service process; (3) focusing on the service offer and the service process together. However, other studies (Voss \& Hsuan, 2009) suggest looking at the decoupling through the customer's prism, recalling that the purpose of modular design application for services is enabling variation to meet customer needs. The authors propose that customisation can be achieved either in a combinatorial manner, where the company, at the customer's request, assembles the elements of the service offering and the required sub-processes, creating a unique service or through a set of standardised services (menu driven). These two approaches raise an objective for further research - to define what criteria should a service organisation consider when deciding to adopt modularity and getting a balance between service customisation and standardisation.

Another aspect of modular design application for services is related to the fact that every service organisation should act rationally and aim at the productivity of the entire service delivery system, not just focusing on optimising the delivery process for service customisation. Service delivery needs resources. As a co-production takes place during the service delivery (Carlborg \& Kindström, 2014; Skačkauskienè \& Vesterte, 2018), these resources may belong to both the provider and the customer. The use of the provider's resources in service delivery is part of the operations management of the organisation (Butkus, 2002). Any organisation should manage its resources so that they are available at the moment they are needed to make the product and to optimise their use. Achieving such dynamic management is possible through a modular organisational structure (Zakarevičius, 2002), which also allows for the transfer of separate parts of service delivery process to remote service providers (Bask, Leseure, Lipponen, Rajahonka, \& Tinnilä, 2010; Blomberg, 2010). The researchers (Carlborg \& Kindström, 2014; Eissens-van der Laan et al., 2016) notice that there is no sufficient assessment of the influence of the customer as a co-producer of the service and the owner of necessary resources on the service modularity in the scientific literature. However, studies draw attention (Carlborg \& Kindström, 2014; Eissens-van der Laan et al., 2016) that being extremely active (i.e. the customer has a firm control over the service) or passive (i.e. the customer does not provide the necessary information, delays in performing the tasks assigned, etc.) customer participation influences the efficiency of the service process. Therefore, the service provider should have a good understanding of (1) what the customer can or cannot do before designing the service modules, what resources (knowledge, skills) the customer can offer and (2) how the customer will use the service. The uncertainty of customer participation impact on service delivery implies that modularity is challenging to implement through standardisation and automation of customer service processes, especially at service events. Though, advances in information technology, especially in the field of artificial intelligence, indicate that this can be feasible.

The service modularity would not be sustained if there were no reverse action - assembling the decoupled parts into a whole. The service delivery must be a smooth process; otherwise, it would not ensure that the customer receives the desired service quality. There is a need for coordination between modules that, as highlighted in this section, may be represented by elements of the service offering and sub-processes. Coordination is the management of dependencies (Malone \& Crowston, 1994). It deals with issues of shared resources, customer-provider relationships, process sequencing, and other dependencies. The modular design asserts that modules should be connected through simple, standardised interfaces. These interfaces should represent coordination tasks. Since interface design methods for service delivery are still not sufficiently explored (de Mattos et al., 2019), this issue requires the attention of scientists.

\section{Conclusions}

In order to understand the aspects of modular design application to services, service delivery process must be investigated. Based on the researched notion of process and taking into account the essential differences between services and goods (the service is the product and the process in which the customer is involved), the study examined the service delivery process through lenses of customer and service provider thus drawing an extensive view of it. The analysis has revealed that there are parts of the service delivery process that the provider as a subject cannot entirely manage. However, those parts (episodes, service events, i.e. where the customer participates) affect the service delivery process and service quality for which the provider is responsible.

Service customisation without increasing costs is the driver that motivates a service provider to apply modular design to services as this is the way to attain a competitive advantage in the market. Modular design principles allow uncovering a balance between two oppositions - standardisation, which reduces service costs and increases the provider's productivity, and customisation that increases customer satisfaction but also increases the provider's costs. The application of modular design makes the individual elements of the service delivery process standardised, allowing them to be flexibly combined or separated. The paper stated that in order to achieve service modularity the provider should apply methods of standardisation and automation to the three dimensions: (1) service offering; (2) parts of the service process that are managed by the provider; (3) organisational structure of the provider. The study addressed the 
fact that the choice of methods for achieving service modularity depends on the nature of the services. Undoubtedly, for some services, modular design can be applied across all three dimensions, for other services - just one.

Because modular design is only applicable to managed parts of the service delivery process, it is difficult to standardise those parts of the service that the customer is involved. The high amount of information and numerous possible solutions characterise those parts. However, advances in information technology and communication, especially in the field of artificial intelligence, show that large amounts of information can be processed very quickly, so there is scope for automating such parts of the service process, leaving the customer with the impression that (s)he receives a unique service.

Any service must be provided smoothly so that the customer remains satisfied. The decoupling of the service delivery process into modules implies a coordination problem that should be addressed through properly designed module interfaces which research is one of the most needed in the context of service modularity.

\section{References}

Bagdonienė, L., \& Hopenienė, R. (2004). Paslaugu marketingas ir vadyba [Service marketing and management]. Kaunas: Technologija.

Baldwin, C. Y., \& Clark, K. B. (2000). Design rules: The power of modularity (4 ed., Vol. 1). Cambridge, MA: The MIT Press. https://doi.org/10.7551/mitpress/2366.001.0001

Bask, A., Leseure, M., Lipponen, M., Rajahonka, M., \& Tinnilä, M. (2010). The concept of modularity: Diffusion from manufacturing to service production. Journal of Manufacturing Technology Management, 21(3), 355-375. https://doi.org/10.1108/17410381011024331

Bask, A., Lipponen, M., Rajahonka, M., \& Tinnilä, M. (2011). Framework for modularity and customization: Service perspective. Journal of Business \& Industrial Marketing, 26(5), 306-319. https://doi.org/10.1108/08858621111144370

Bergh, D. G. v., Ghijsen, P. W. T., Gelderman, C. J., \& Tuninga, R. S. J. (2015). Waiting in multi-stage services: an exploration across service industries. International Journal of Business and Globalisation, 14(2), 187-207. https://doi.org/10.1504/IJBG.2015.067435

Blomberg, J. (2010). Work in the service economy. In G. Salvendy \& W. Karwowski (Eds.), Introduction to service engineering (pp. 48-70). Hoboken, NJ: John Wiley \& Sons, Inc.

Brax, S. A., Bask, A., Hsuan, J., \& Voss, C. (2017). Service modularity and architecture - an overview and research agenda. International Journal of Operations \& Production Management, 37(6), 686-702. https://doi.org/10.1108/ijopm-03-2017-0191

Broekhuis, M., van Offenbeek, M., \& Eissens-van der Laan, M. (2017). What professionals consider when designing a modular service architecture? International Journal of Operations \& Production Management, 37(6), 748-770. https://doi.org/10.1108/ijopm-05-2015-0306

Butkus, F. S. (2002). Operatyvus ịmonès veiklos valdymas [Company operations management]. Vilnius: Technika.

Carlborg, P., \& Kindström, D. (2014). Service process modularization and modular strategies. Journal of Business \& Industrial Marketing, 29(4), 313-323. https://doi.org/10.1108/JBIM-08-2013-0170

Clark, G., Johnston, R., \& Shulver, M. (2000). Exploiting the service concept for service design and development. In J. A. Fitzsimmons \& M. J. Fitzsimmons (Eds.), New service development: creating memorable experiences (pp. 71-91). Thousand Oaks, CA: SAGE Publications, Inc. https://doi.org/10.4135/9781452205564.n4

Edvardsson, B., \& Olsson, J. (1996). Key concepts for new service development. The Service Industries Journal, 16(2), 140-164. https://doi.org/10.1080/02642069600000019

Eissens-van der Laan, M., Broekhuis, M., van Offenbeek, M., \& Ahaus, K. (2016). Service decomposition: A conceptual analysis of modularizing services. International Journal of Operations \& Production Management, 36(3), 308-331. https://doi.org/10.1108/ijopm-06-2015-0370

Ercsey, I. (2017). The role of customers' involvement in value co-creation behaviour is value co-creation the source of competitive advantage? Journal of Competitiveness, 9(3), 51-66. https://doi.org/10.7441/joc.2017.03.04

Geum, Y., Kwak, R., \& Park, Y. (2012). Modularizing services: A modified HoQ approach. Computers \& Industrial Engineering, 62(2012), 579-590. https://doi.org/10.1016/j.cie.2011.11.006

Goldstein, S. M., Johnston, R., Duffy, J., \& Rao, J. (2002). The service concept: The missing link in service design research? Journal of Operations Management, 20(2), 121-134. https://doi.org/10.1016/S0272-6963(01)00090-0

Grönroos, C. (2016). Service management and marketing: Managing the service profit logic (4 ed.). Hershey, PA: John Wiley \& Sons, Inc.

Heskett, J. L. (1986). Managing in the service economy. Boston, MA: Harvard Business School Press.

Jain, R., Aagja, J., \& Bagdare, S. (2017). Customer experience - a review and research agenda. Journal of Service Theory and Practice, 27(3), 642-662. https://doi.org/10.1108/JSTP-03-2015-0064

Johnston, R., Clark, G., \& Shulver, M. (2012). Service operations management: Improving service delivery (4 ed.). Essex, UK: Pearson Education.

Levin, M. S. (2015). Modular system design and evaluation. London, UK: Springer. https://doi.org/10.1007/978-3-319-09876-0

Lillrank, P. (2010). Service Processes. In G. Salvendy \& W. Karwowski (Eds.), Introduction to Service Engineering. Hoboken, NJ: John Wiley \& Sons, Inc. 
Lipkin, M. (2016). Customer experience formation in today's service landscape. Journal of Service Management, 27(5), 678-703. https://doi.org/10.1108/JOSM-06-2015-0180

Løkkegaard, M., Mortensen, N. H., \& McAloone, T. C. (2016). Towards a framework for modular service design synthesis. Research in Engineering Design, 27(3), 237-249. https://doi.org/10.1007/s00163-016-0215-6

Malone, T. W., \& Crowston, K. (1994). The interdisciplinary study of coordination. ACM Computing Surveys, 26(1), 87-119. https://doi.org/10.1145/174666.174668

de Mattos, C. S., Fettermann, D. C., \& Cauchick-Miguel, P. A. (2019). Service modularity: Literature overview of concepts, effects, enablers, and methods. The Service Industries Journal. https://doi.org/10.1080/02642069.2019.1572117

Merrifield, R., Calhoun, J., \& Stevens, D. (2008). The next revolution in productivity. Harvard Business Review, 2008(June), 7380. https://hbr.org/2008/06/the-next-revolution-in-productivity

Nätti, S., Ulkuniemi, P., \& Pekkarinen, S. (2017). Implementing modularization in professional services: The influence of varied knowledge environments. Knowledge and Process Management, 24(2), 125-138 https://doi.org/10.1002/kpm.1538

O’Loughlin, D., Szmigin, I., \& Turnbull, P. (2004). From relationships to experiences in retail financial services. The International Journal of Bank Marketing, 22(7), 522-539. https://doi.org/10.1108/02652320410567935

Pekkarinen, S., \& Ulkuniemi, P. (2008). Modularity in developing business services by platform approach. The International Journal of Logistics Management, 19(1), 84-103. https://doi.org/10.1108/09574090810872613

Shostack, G. L. (1977). Breaking free from product marketing. The Journal of Marketing, 41(2), 73-80. https://doi.org/10.2307/1250637

Skačkauskienè, I., \& Vestertè, J. (2018). Paslaugos sampratos aktualizavimas šiuolaikinèje vadyboje / Redefining service notion in contemporary management. Mokslas - Lietuvos ateitis / Science - Future of Lithuania, 10(2018), 1-9. https://doi.org/10.3846/mla.2018.364

Storey, C., \& Easingwood, C. J. (1998). The augmented service offering: A conceptualization and study of its impact on new service success. Journal of Product Innovation Management, 15(4), 335-351. https://doi.org/10.1016/S0737-6782(97)00107-0

Sundbo, J. (1994). Modulization of service production and a thesis of convergence between service and manufacturing organizations. Scandinavian Journal of Management, 10(3), 245-266. https://doi.org/10.1016/0956-5221(94)90002-7

Tuunanen, T., Bask, A., \& Merisalo-Rantanen, H. (2012). Typology for modular service design: Review of literature. International Journal of Service Science, Management, Engineering, and Technology, 3(3), 99-112. https://doi.org/10.4018/jssmet.2012070107

Uzkurt, C. (2010). Customer participation in the service process: A model and research propositions. International Journal of Services and Operations Management, 6(1), 17-37. https://doi.org/10.1504/IJSOM.2010.029487

Voss, C. A., \& Hsuan, J. (2009). Service architecture and modularity. Decision Sciences, 40(3), 541-569. https://doi.org/10.1111/j.1540-5915.2009.00241.x

Wirtz, J., \& Lovelock, C. (2018). Essentials of services marketing (3 ed.). Essex, UK: Pearson Education.

Zakarevičius, P. (2002). Vadyba: genezé, dabartis, tendencijos [Management: genesis, present, trends]. Kaunas: Vytauto Didžiojo universitetas. 